\title{
Bartholin's Abscess with Bacterial Vaginosis Coinfection Successfully Treated with a Modified Word Catheter and Combined Antibiotics
}

\author{
Nugrah Santo ${ }^{1}$, Muhlis Muhlis ${ }^{1 *}$, Muji Iswanty ${ }^{1}$, Idrianti Idrus $^{1}$, Nasrum Massi $^{2}$ \\ ${ }^{1}$ Department of Dermatology and Venereology, Faculty of Medicine, Hasanuddin University, Makassar, South Sulawesi, \\ Indonesia; ${ }^{2}$ Department of Microbiology, Faculty of Medicine, Hasanuddin University, Makassar, South Sulawesi, Indonesia
}

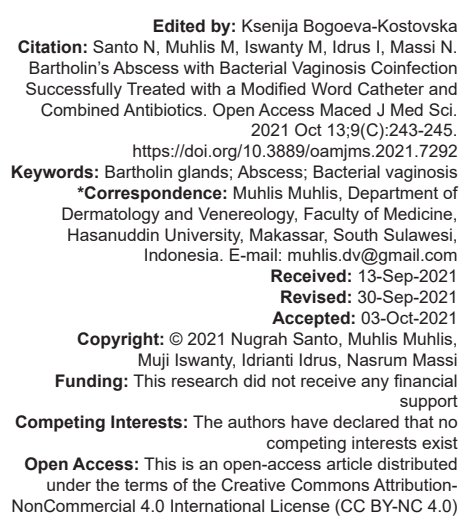

Edited by: Ksenija Bogoeva-Kostovsk Citation: Santo N, Muhlis M, Iswanty M, Idrus I, Massi N. Bartholin's Abscess with Bacterial Vaginosis Coinfection Successfully Treated with a Modified Word Catheter an Combined Antibiotics. Open Access Maced J Med Sci. https://doi.org/10.3889/oamims 2021.7292 Keywords: Bartholin glands; Abscess; Bacterial vaginosis *Correspondence: Muhlis Muhlis, Department of Dermatology and Venereology, Faculty of Medicine Hasanuddin University, Makassar, South Sulawesi, Indonesia. E-mail: muhlis.dv@gmail.com Received: 13-Sep-202 Revised: $30-$ Sep-2021
Accepted: $03-O c t-2021$ Copyright: ๑ 2021 Nugrah Santo, Muhlis Muhlis Muji Iswanty, Idrianti Idrus, Nasrum Massi Funding: This research did not receive any financial competing interests exist

Open Access: This is an open-access article distributed under the terms of the Creative Commons AttributionNonCommercial 4.0 International License (CC BY-NC 4.0)

\section{Abstract}

BACKGROUND: Bartholin's abscess is an infection of the Bartholin gland that often occurs in women of childbearing age. The prevalence of Bartholin's abscess is $2 \%$ in the female population worldwide. Patients often complain dyspareunia with a high recurrence rate. Bacterial Vaginosis (BV) is a syndrome of changes in the vaginal ecosystem that occurs spontaneously in sexually active women. BV can contribute to the development of a Bartholin's gland abscess.

CASE REPORT: A 30-year-old woman came with the chief complaint of a $5 \mathrm{~cm} \times 5 \mathrm{~cm}$ erythematous, tender, and mobile mass on the right side of the labia majora. In addition, the patient also experienced recurrent vaginal discharge. The patient was diagnosed with Bartholin's abscess with BV coinfection that was successfully treated with a modified word catheter and combination of antibiotics that showed no recurrence.

CONCLUSION: Combination of modified word catheter and antibiotics can be a simple yet effective way in treating Bartholin's abscess.

\section{Introduction}

The Bartholin's gland is an essential organ of the female reproductive system. The organ's main function is to secrete mucus to ensure vaginal and vulval lubrication [1]. The pea-sized gland is not palpable except in the presence of infection [2]. The Bartholin's glands are prone to infections and abscess formation, which may result in vestibular pain and dyspareunia [1]. Bartholin's gland infection can involve the main duct (which opens near the junction of the anterior two-thirds and posterior one-third of the labia majora) as well as the minor ducts and glandular acini. Ductal inflammation and obstruction can lead to Bartholin's abscess or cysts, which can reach 1-8 cm in diameter [3]. Bartholin's cyst is a common problem usually affecting women in the reproductive age group, especially between the ages of 20-30 years [4]. The prevalence of Bartholin cyst is estimated approximately at $2 \%$ worldwide [5].

The etiology of Bartholin it is commonly involves Neisseria gonorrhea or Chlamydia trachomatis; abscesses often contain enteric and vaginal Gram-negative rods and anaerobes [3].
Bartholin's gland abscesses are mainly caused by opportunistic bacteria [6].

Treatment of symptomatic Bartholin's duct abscess can be challenging. Treatment options include antibiotics, wound dressings, and simple drainage. Alternative treatments include fistulization to create new duct opening, marsupialization, or excision of the gland [7].

Bacterial Vaginosis (BV), formally known as Gardnerella vaginitis, is the most prevalent cause of abnormal vaginal discharge in women of childbearing age. The typical clinical manifestation is recurrent fishy-smelling vaginal discharge, often around the time of menstruation. $\mathrm{BV}$ is a risk factor for complications in pregnancy such as secondtrimester miscarriage, spontaneous preterm birth, and post-cesarean section endometritis. BV is also associated with sexually transmitted diseases such as HIV. BV usually responds to antibiotic treatment but has a high recurrence rate [8]. The vaginal discharge should be examined microscopically to determine if the patient has BV or trichomoniasis, which can contribute to the development of a Bartholin's gland abscess [9]. 
A-30-year-old woman presented to the dermatovenereology clinic with a chief complaint of a vaginal mass 4 days before accompanied with intermittent pain. Initially, the mass was the size of a pea that then enlarged a few days later. The patient also complained of fever and vaginal discharge. The patient said that she had experienced the same complaint twice within the past year and was treated with two kinds of antibiotics which reduced the size of the mass. The patient often experienced vaginal discharge with fishy smelling after sexual intercourse.

On physical examination, vital signs were within normal limits, and venereological examination found a $5 \times 5 \mathrm{~cm}$ mobile, tender, and erythematous abscess on the right labia majora with thin homogenous vaginal discharge (Figure 1a).

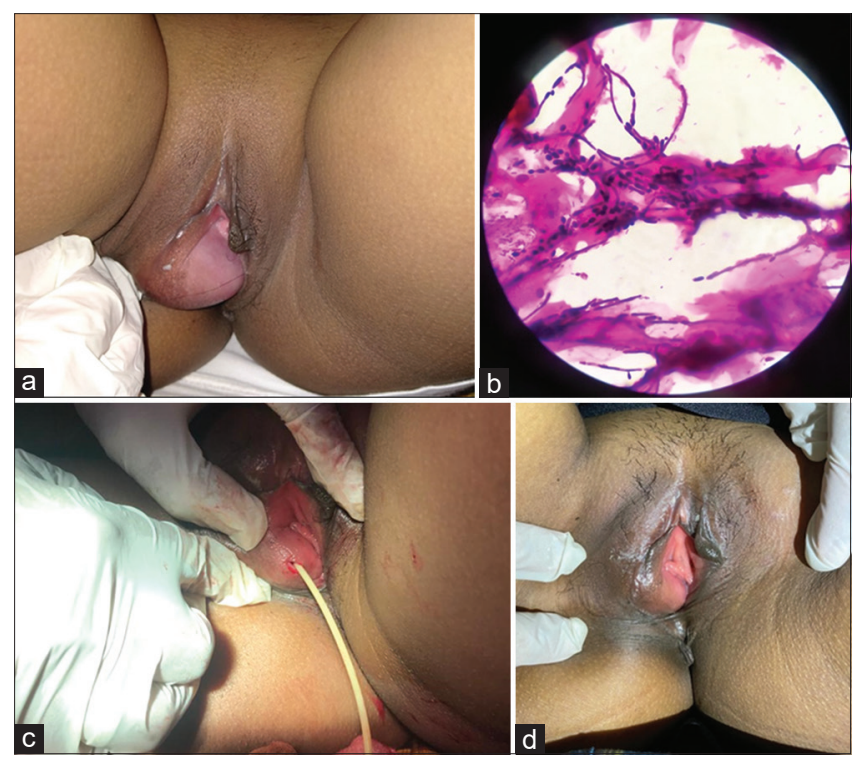

Figure 1: Presence of abscess on the right labia majora (a); Grampositive bacilli bacteria (b); Fistulization and Insertion of word catheter on the abscess (c); Three weeks follow-up showed significant clinical improvements $(d)$

Vaginal discharge sample was taken for testing, and gram staining was positive for bacilli bacteria +3 , along with yeast and hyphae (Figure 1b). Nugent scoring was seven, indicating BV. Pus culture from the abscess found positive-gram bacteria identified as Staphylococcus haemolyticus.

The patient was given metronidazole $500 \mathrm{mg}$ tablet orally twice daily for 7 days. In addition, the patient was also educated to delay sexual intercourse during treatment and maintain personal hygiene, especially around the genital area. On the next day, we performed fistulization and placement of a modified word catheter utilizing a no.10 Foley catheter. We started the procedure by making a stab incision using a no.15 blade on the abscess. Pus was then drained completely and irrigated with sterile saline. The modified word catheter was then placed into the gland through the stab incision and the balloon was distended with saline (Figure 1c). The catheter was the left in place until it falls out spontaneously, usually in the next
3-6 weeks. The patient was then given oral $500 \mathrm{mg}$ levofloxacin once daily for 7 days. A follow-up on the patient 3 weeks after the procedure, found significant improvements on the lesion with the reduction in size and no vaginal discharge or bleeding (Figure 1d).

\section{Discussion}

The Bartholin's gland is a tubuloalveolar gland with acini composed of mucin secreting columnar, cuboidal, squamous, or transitional columnar epithelium [5]. The function of the Bartholin glands is to continuously produce colorless serous fluid for introitus lubrication. Serous fluid is then drained through the Bartholin ducts onto the vestibular outlet just outside the hymenal ring. Blockage or prior damage to this structure can result in fluid accumulation, ductal dilatation, ductal cyst, or abscess formation. Infected cysts can result in Bartholin duct or gland abscess, with incidence of abscesses 3 times more common than cysts [10].

Bartholin duct or gland abscesses can be categorized as mild, moderate, or severe. A mild case is defined as purulent infection without systemic symptoms. A moderate abscess is defined as purulent infection accompanied with systemic symptoms, such as fever [11]. In our case, the abscess can be categorized as a moderate case due to the presence of fever. Severity of pain varies from mild to severe and can develop within 2-4 days. Lesions can be indurated, with diameters ranging from 4 to $5 \mathrm{~cm}$ but can be as large as $8 \mathrm{~cm}$ [10]. Other symptoms include pus discharge and dyspareunia. Physical examination in our case revealed a unilateral, tender, inflamed posterior labial mass accompanied with inflammation, pain, and dyspareunia.

Bartholin's abscesses have several surgical treatment options such as fistulization. The aim of this technique is to create a new duct opening through incision and drainage through the placement of a word catheter [11]. The word catheter is a short rubber tube measuring around $6 \mathrm{~cm}$, the tip of which has a small balloon, which holds $3 \mathrm{ml}$ of saline. In our case because there was no word catheter available at the time, we modified a no.10 Foley catheter in place for the word catheter.

A stab incision was made within the introitus, external to the hymenal ring around the duct orifice, the abscess was then drained, and a catheter inserted under local anesthetic infiltration. The balloon was inflated with $2-3 \mathrm{ml}$ of saline and the free end can be tucked into the vagina [11]. The catheter was then left in place until it falls out spontaneously, which usually occurs within 3-6 weeks [9]. Fistulization and placement of a word catheter are a relatively simple and straightforward method that can be completed 
in an outpatient setting [12]. This process creates a new duct opening for the lesion to continuously drain hence increasing healing time. The word catheter can be inserted 3-6 weeks to allow for re-epithelization of the duct [9]. A 3 week follow-up showed satisfactory result. This method combined with antibiotic regiments of metronidazole and levofloxacin will further increase effectiveness of management and act against both aerobic and anaerobic bacteria [9].

$\mathrm{BV}$ is one of the most common vaginal infections in reproductive aged women. It is characterized by the decrease of beneficial lactobacilli bacteria with an overgrowth of anaerobic bacteria. The cause of BV is not fully understood due to the great diversity and complexity of microorganisms involved. However, it may be sexually assisted and sexually transmitted. In women with $B V$, the native vaginal flora-hydrogen peroxide producing lactobacilli responsible for maintaining an acidic environment - is replaced with invasive pathogens. Over 50\% of women with BV experienced an unpleasant thin vaginal malodorous discharge, which is associated with a significant negative impact on self-esteem, sexual relationships, and quality of life [13]. About $10 \%$ potassium hydroxide test on the sample from the vaginal discharge also produced similar fishy odor characteristic of BV.

The gold standard for diagnosing BV is through Gram staining and Nugent scoring [13]. Grampositive bacilli bacteria found in Gram staining in this case with Nugent score 7, indicated BV. The latest CDC recommendation treatment for $\mathrm{BV}$ is metronidazole $500 \mathrm{mg}$ orally twice daily for 7 days, with the alternative regimen of clindamycin $300 \mathrm{mg}$ orally twice daily for 7 days [14]. Metronidazole along with levofloxacin provided satisfactory results in the treatment of the patient in this case.

\section{Conclusion}

Bartholin's abscess with BV coinfection can be treated using the combination of insertion of a modified word catheter along with the combination of metronidazole and levofloxacin. The procedure is simple, straightforward, and can be performed in an outpatient setting.

\section{References}

1. Lee MY, Dalpiaz A, Schwamb R, Miao Y, Waltzer W, Khan A Clinical pathology of Bartholin's glands: A review of the literature. Curr Urol. 2014;8(1):22-5. https://doi.org/10.1159/000365683 PMid: 6195958

2. Patil S, Sultan A, Thakar R. Bartholin's cysts and abscesses. J Obstetr Gynaecol. 2007;27(3):241-5. https://doi.org/10.1136/ sti.76.6.498

3. Holmes KK, Stamm WE, Sobel JD. Lower genital tract infection syndromes in women. In: Holmes KK, Sparling PF, Stamm WE, Piot P, Wasserheit JN, Corey $L$, et al., editors. Sexually Transmitted Diseases. $4^{\text {th }}$ ed. Chicago: McGraw-Hill Education; 2007. p. $987-1016$

4. Aghajanian A, Bernstein L, Grimes D. Bartholin's duct abscess and cyst: A case-control study. Southern Med J. 1994;87(1):269. https://doi.org/10.1097/00007611-199401000-00006 PMid:8284713

5. Soydinç HE, Sak ME, Evsen MS, Çaça FN. Heterotopically located bartholin's cyst. Eur J Gen Med. 2012;9(1):36-8. https:// doi.org/10.29333/ejgm/82513

6. Bhide A, Nama V, Patel S, Kalu E. Microbiology of cysts/abscesses of Bartholin's gland: Review of empirical antibiotic therapy against microbial culture. J Obstetr Gynaecol. 2010;30(7):701-3. https:// doi.org/10.3109/01443615.2010.505672

PMid:20925614

7. Krissi H, Shmuely A, Aviram A, From A, Edward R, Peled Y. Acute Bartholin's abscess: Microbial spectrum, patient characteristics, clinical manifestation, and surgical outcomes. Eur J Clin Microbiol Infect Dis. 2016;35(3):443-6. https://doi. org/10.1007/s10096-015-2557-9

PMid:26740325

8. Hay P. Bacterial vaginosis. F1000Res. 2017;6:1761 PMid:29043070

9. Bieber EJ, Sanfilippo JS, Horowitz IR, editors. Clinical Gynecology. Cambridge: Cambridge University Press; 2015.

10. Policar M. Management of Vulvar and Bartholin Duct Infections: American Society for Colposcopy and Cervical Pathology Webinar 2017. Available from: http://www.asccp.org/elearningwebinars-courses. [Last accessed on 2020 Jun 01].

11. Dole DM, Nypaver C. Management of Bartholin duct cysts and gland abscesses. J Midwif Womens Health. 2019;64(3):337-43. https://doi.org/10.1111/jmwh.12937

12. Bora SA, Condous G. Bartholin's, vulval and perineal abscesses Best Pract Res Clin Obstetr Gynaecol. 2009;23(5):661-6. https://doi.org/10.1016/j.bpobgyn.2009.05.002 PMid: 19647493

13. Bagnall $P$, Denise $R$. Bacterial vaginosis: $A$ practical review. J Am Acad PA. 2017;30(12):15-21.

PMid:29135564

14. Centers for Disease Control and Prevention. Sexually Transmitted Diseases Treatment Guidelines, 2021, Morbidity and Mortality Weekly Report. Atlanta: Centers for Disease Control and Prevention; 2021. https://doi.org/10.1093/ofid/ofv131.117 